\title{
Investigation of Predictive Value of Complete Blood Count in the Diagnosis of Acute Complicated Appendicitis
}

\section{Tam Kan Sayımının Akut Komplike Apandisitin Tanısındaki Kestirim Değerinin Araştırılması}

\author{
๑ Yusuf Günay, ๑ Illhan Taşdöven, ๑ Ramazan Kozan, • Şükran Koca* • E Emrah Çağlar** \\ Bülent Ecevit University Faculty of Medicine, Department of General Surgery, Zonguldak, Turkey \\ *Bülent Ecevit University Faculty of Medicine, Department of Radiological, Zonguldak, Turkey \\ **Bülent Ecevit University Faculty of Medicine, Department of Emergency Medicine, Zonguldak, Turkey
}

Abstract

Aim: Whether it is possible to differentiate complicated from uncomplicated acute appendicitis (AA) by using complete blood count $(C B C)$ is controversial. In this study, we analysed the predictive value of $C B C$ in differentiating complicated from uncomplicated $A A$.

Methods: In this retrospective study, we analyzed records of patients who underwent appendectomy in our clinic between January 1, 2015 and January 1, 2018. The demographic data and CBC reports were collected

Results: Two hundred thirty-five patients underwent appendectomy due to AA. Of the 235 patients, 164 (69.8\%) had non-complicated (WBC), red cell distribution width (RDW), platelet and plateletcrit count were significantly higher in patients with complicated $A A$ than in those with uncomplicated AA $(p=0.001 ; p<0.01, p=0.049$, and $p=0.006$, respectively). Both the mean neutrophil count and percentage were statistically higher in complicated AA patients $(p=0.001$ and $p<0.01$, respectively). The basophil-to-lymphocyte ratio $(B L R)$ and neutrophilto-lymphocyte ratio (NLR) were significantly higher in patients with complicated $A A$ ( $p=0.001$ and $p<0.01$, respectively). Logistic regression analysis showed that WBC and RDW were independent diagnostic factors for complicated AA [odss ratio (OR) 5.079 (95\% confidence interval (Cl): 2.29-11.24 and OR 1.412 (95\% Cl: 1.1-1.98), respectively] $(p<0.001$ and $p=0.046$, respectively). The sensitivity, specificity, positive and negative predictive values in complicated AA for BLR were $67.35 \%$, $64.04 \%, 44.6 \%$ and $82 \%$, and for NLR were $73.47 \%, 66.67 \%, 48.6 \%$ and $85.4 \%$, respectively.

Conclusion: Elevated NLR, BLR and RDW, WBC and neutrophil count may help differentiate complicated from non-complicated AA.

Keywords: Acute appendicitis, complete blood count, complicated appendicitis and $71(30.2 \%)$ had complicated AA. The mean white blood count

Öz

Amaç: Komplike akut apandisitin (AA) ayırıcı tanısında tam kan sayımının kullanılabileceği konusunda tartışmalar devam etmektedir. Bu çalışmada tam kan sayımının komplike AA ayııı tanısındaki kestirim değeri araştıııldı.

Yöntemler: Ocak 2015 ile Ocak 2018 tarihleri arasında apendektomi ameliyatı olan hastaların dosyaları geriye dönük incelendi. Demografik verilerle tam kan sayımının sonuçları toplandı.

Bulgular: İki yüz otuz beş hasta AA nedeni ile apendektomi ameliyatı oldu. Bu 235 hastadan, 164'ünde $(\% 69,8)$ non-komplike AA tespit edilirken 71 'inde $(\% 30,2)$ komplike AA bulundu. Ortalama beyaz küre sayısı (WBC), kırmızı küre dağılım genişliği (RDW), trombositlerin sayımı ve plateletcrit serum düzeyleri komplike $A A$ olan hastalarda anlamlı derecede yüksek (sırasıyla, $p=0,001 ; p<0,001 ; p=0,049 ; p=0,006$ ). Hem nötrofil sayısı hemde nötrofilin yüzdelik oranı komplike AA olan hastalarda anlamlı derecede yüksek bulundu (sırasıyla, $p=0,001$; $p<0,01)$. Komplike olmayan AA'larla karşılaştıııldığında komplike $A A$ olan hastalarda hem basofil-lenfosit oranı (BLR) hem de nötrofil-lenfosit oranı (NLR) anlamlı derecede yüksek bulundu (sırasıyla, $p=0,001$; $p<0,01)$. Multivariant analiz ile yapilan incelemede $W B C$ ve $R D W ' n i n$ komplike $A A^{\prime}$ da bağımsız tanısal değeri olduğu tespit edildi [tahmini rölatif risk 5,079 \%95 güven aralığı (GA): 2,29-11,24; $p<0,001$ ]; RDW için tahmini rölatif risk 1,412 (\%95 GA:1,01-1,98; $p=0,046)$. Komplike AA'da BLR için duyarlılık \%67,35; özgüllük \%64,04; pozitif kestirim değeri $\% 44,6$ ve negatif kestirim değeri \%82 bulunurken NLR için duyarlılık \%73,47; özgüllük \%66,67; pozitif kestirim değeri \%48,6 ve negatif kestirim değeri \%85,4 olarak tespit edildi.

Sonuç: Yüksek NLR BLR ve RDW değerleri ile birlikte artmış WBC ve nötrofil sayımı komplike AA'nın ayırıcı tanısında kullanılabilir.

Anahtar Sözcükler: Akut apandisit, tam kan sayımı, komplike apandisit

Address for Correspondence/Yazışma Adresi: Yusuf Günay

Bülent Ecevit University Faculty of Medicine, Department of General Surgery, Zonguldak, Turkey

Phone: +90 5339601365 E-mail: drygunay@gmail.com ORCID ID: orcid.org/0000-0002-6518-9997

Received/Geliş Tarihi: 19 July 2018 Accepted/Kabul Tarihi: 03 September 2018

Copyight 2019 by The Medical Bulletin of University of Health Sciences Haseki Training and Research Hospital

The Medical Bulletin of Haseki published by Galenos Yayınevi.

${ }^{8}$ Telif Hakkı 2019 Sağlık Bilimleri Üniversitesi Haseki Eğitim ve Araştırma Hastanes Haseki Tıp Bülteni, Galenos Yayınevi tarafından yayınlanmıştır. 


\section{Introduction}

Acute appendicitis (AA) is the most common cause of abdominal surgical emergency in the world $(1,2)$. Although it is very common, accurate diagnosis sometimes can be very challenging (3). Wrong or delayed diagnosis may cause unnecessary risk of complicated AA (4), therefore, correct and timely diagnosis is very important $(5,6)$. The diagnosis generally depends on the clinical evaluation and abdominal imaging such as ultrasound and computed tomography (7). Nonetheless, problems may exist with radiological imaging in some hospitals due to unavailability of imaging equipment (8-10).

Complete blood count (CBC) is used as a part of routine tests for AA. It has been well known that white blood cell count (WBC) and neutrophil count are increased in AA (11). However, their sensitivity and specificity are low for accurate diagnosis (12). Although, some CBC parameters such as neutrophil-to-lymphocyte ratio (NLR), platelet, mean platelet volume (MPV), plateled distribution width (PDW) and red cell distribution width (RDW) have been studied for the diagnosis of $A A$, it is not clear whether they can be used in differentiating complicated AA from noncomplicated AA (13-18). Although few studies have been studied to identify $C B C$ components for differentiating complicated from non-complicated $A A$, the value of $C B C$ has yet to be investigated in details (19-22).

This study was planned to evaluate the predictive value of all components of $C B C$ in differentiating noncomplicated AA from complicated AA.

\section{Methods}

This retrospective study was performed on adults who underwent appendectomy for AA from January 1, 2015 to January 1, 2018. Data was collected retrospectively and analyzed. The study was approved by Bülent Ecevit University Ethical Board Review and registered with a number of 2018-145-23/05. Two hundred thirty-five patients were included in this study. Inclusion criteria were being older than 18 years of age, nonpregnant and having had initial blood test prior to surgery. Patients with a pathologically normal appendix were excluded from the study.

The patients were divided into two groups based on pathological reports as complicated and non-complicated AA. Complicated AA was considered perforated appendicitis. The data collected for the study included age, gender, WBC, neutrophil count and percentage, lymphocyte count and percentage, monocyte count and percentage, eosinophil count and percentage, basophil count and percentage, red blood cell (RBC), RDW, PLT count, plateletcrit (PCT), PDW, MPV, NLR, lymphocyteto-monocyte ratio (LMR), platelet-to-lymphocyte ratio
$(P L R)$, eosinophil-to-lymphocyte ratio (ELR), basophil-toneutrophil ratio (BNR), basophil-to-lymphocyte ratio (BLR).

\section{Statistical Analysis}

The results are defined as percentage (\%) and as mean \pm standard deviation. The results were analyzed by chisquare test, Student's t-test and the Mann-Whitney $U$ tests. Logistic regression analysis was used as multivariate analysis. The parameters that predict complicated AA were calculated by receiver operating characteristic (ROC) curve analysis. The confidence interval $(\mathrm{Cl})$ was set at $95 \%$ and a p-value of less than 0.05 was considered statistically significant. Number Cruncher Statistical System (NCSS) software version 2007 (NCSS LLC, Kaysville, Utah, USA) was used for statistical analysis.

\section{Results}

Two hundred thirty-five patients underwent appendectomy due to AA. Of these patients, 134 (62\%) had open surgery and in 90 (38\%), the surgery was commenced laparoscopically but was converted to open surgery in 11 (12\%). One hundred twenty-one (51\%) patients were male and $114(49 \%)$ were female. The mean age was $41 \pm 19$ years (range:16-86).

Of the 235 patients, 164 (69.8\%) patients had noncomplicated AA, while 71 (30.2\%) had complicated AA. The mean age of the patients with complicated AA was statistically significantly lower than patients with noncomplicated AA ( $36 \pm 20$ vs $34 \pm 18, p=0.035)$. There was no significant difference in the rate of female gender between the groups ( $53 \%$ vs $43 \%, p=0.872$ ).

The results of univariant analysis are shown in Tables 1 , 2 and 3 . There was no statistically significant difference in the mean RBC, MCV, MPV, and PDW ( $p>0.05)$. The mean WBC, RDW, PLT and PCT was significantly higher in patients with complicated AA ( $p=0.001 ; p<0.01, p=0.049$ and $p=0.006$, respectively).

There was no statistically significant difference in the mean lymphocte count $(p>0.05)$, while the lymphocyte percentage was statistically lower in patients with complicated AA compared to those with non-complicated AA $(p=0.001)$. The mean number of monocytes was statistically significantly higher in patients with complicated AA $(p=0.001)$, while the monocyte percentage was not different between the groups ( $p>0.05)$. Both the mean neutrophil count and percentage of neutrophil were statistically significantly higher in patients with complicated AA when compared with non-complicated AA $(p=0.001)$. Although there was no significant difference in the mean eosinophil count between the groups $(p>0.05)$, the eosinophil percentage was statistically higher in patients with complicated AA $(p=0.004)$. The average basophil level was significantly higher in patients with complicated 
AA ( $p=0.001)$, while no significant difference was found in the percent of basophil between the groups ( $p>0.05)$.

There was no significant difference in ELR, BNR, LMR and PLR between the groups ( $p>0.05)$, while the BLR and NLR were statistically higher in patients with complicated AA than in those with non-complicated AA ( $p=0.001$, Table 3).
A logistic regression analysis revealed the potential diagnostic factors in complicated AA; WBC, RDW, PLT, $\mathrm{PCT}$, monocyte, eosinophil percentage, BLR and NLR were analyzed. Of these values, only WBC and RDW were determined as independent diagnostic factors [odds ratio (OR) 5.079 (95\% Cl: 2.29-11.24, p<0.001, OR 1.412 (95\%

\begin{tabular}{|c|c|c|c|c|}
\hline & \multirow[t]{2}{*}{ Mean \pm SD } & \multicolumn{2}{|l|}{ Groups } & \multirow[b]{2}{*}{$\mathrm{p}$} \\
\hline & & Non-complicated AA $(n=164)$ & Complicated AA $(\mathrm{n}=71)$ & \\
\hline WBC $\left(\times 10^{3} / \mathrm{mm}^{3}\right)$ & $13.37 \pm 4.88$ & $10.91 \pm 3.15$ & $18.96 \pm 3.24$ & ${ }^{\mathrm{b}} 0.001$ ** \\
\hline $\mathrm{RBC}\left(\times 10^{3} / \mathrm{mm}^{3}\right)$ & $4.65 \pm 0.66$ & $4.58 \pm 0.53$ & $4.8 \pm 0.87$ & ${ }^{b} 0.110$ \\
\hline RDW (\%) & $15.1 \pm 3.57$ & $14.28 \pm 2.73$ & $16.97 \pm 4.48$ & $\mathrm{a} 0.001$ ** \\
\hline $\mathrm{PLT}\left(\times 10^{3} / \mathrm{mm}^{3}\right)$ & $243.63 \pm 80.57$ & $235.46 \pm 74.01$ & $262.26 \pm 91.93$ & b0.049* \\
\hline PCT (\%) & $0.39 \pm 1.62$ & $0.31 \pm 1.14$ & $0.56 \pm 2.39$ & ${ }^{a} 0.006^{* *}$ \\
\hline MPV (fL) & $8.74 \pm 2.88$ & $8.54 \pm 1.36$ & $9.2 \pm 4.79$ & ${ }^{\mathrm{a}} 0.812$ \\
\hline PDW (\%) & $17.28 \pm 3.68$ & $17.23 \pm 3.56$ & $17.38 \pm 3.98$ & ${ }^{\mathrm{a}} 0.494$ \\
\hline
\end{tabular}

\begin{tabular}{|c|c|c|c|c|}
\hline & \multirow[t]{2}{*}{ Mean \pm SD } & \multicolumn{2}{|l|}{ Groups } & \multirow[b]{2}{*}{$p$} \\
\hline & & Non-complicated AA $(n=164)$ & Complicated AA $(n=71)$ & \\
\hline Lymphocyte $\left(\times 10^{3} / \mathrm{mm}^{3}\right)$ & $1.72 \pm 0.76$ & $1.66 \pm 0.75$ & $1.88 \pm 0.76$ & ${ }^{\mathrm{b}} 0.088$ \\
\hline Lymphocyte percentage (\%) & $14.65 \pm 9.01$ & $16.36 \pm 9.84$ & $10.68 \pm 4.79$ & ${ }^{\mathrm{a}} 0.001^{* *}$ \\
\hline Monocyte $\left(\times 10^{3} / \mathrm{mm}^{3}\right)$ & $1 \pm 0.97$ & $0.95 \pm 1.11$ & $1.11 \pm 0.55$ & ${ }^{\mathrm{a} 0} 0.001^{\text {** }}$ \\
\hline Monocyte percentage (\%) & $7.18 \pm 5.33$ & $7.66 \pm 6.11$ & $6.08 \pm 2.49$ & ${ }^{\mathrm{a}} 0.115$ \\
\hline Neutrophile $\left(\times 10^{3} / \mathrm{mm}^{3}\right)$ & $10.32 \pm 4.66$ & $8.14 \pm 3.15$ & $15.41 \pm 3.48$ & ${ }^{b} 0.001^{* *}$ \\
\hline Neutrophile percentage (\%) & $75.85 \pm 13.81$ & $72.74 \pm 14.92$ & $83.08 \pm 6.57$ & ${ }^{a} 0.001^{* *}$ \\
\hline Eosinophil $\left(\times 10^{3} / \mathrm{mm}^{3}\right)$ & $0.12 \pm 0.16$ & $0.12 \pm 0.15$ & $0.12 \pm 0.18$ & ${ }^{\mathrm{a}} 0.327$ \\
\hline Eosinophil percentage (\%) & $1.06 \pm 1.8$ & $1.23 \pm 2.03$ & $0.68 \pm 1.02$ & ${ }^{a} 0.004^{* *}$ \\
\hline Basophil $\left(\times 10^{3} / \mathrm{mm}^{3}\right)$ & $0.07 \pm 0.14$ & $0.07 \pm 0.15$ & $0.09 \pm 0.12$ & ${ }^{\mathrm{a}} 0.001^{* *}$ \\
\hline Basophil percentage (\%) & $0.61 \pm 0.92$ & $0.65 \pm 1.01$ & $0.52 \pm 0.66$ & ${ }^{\mathrm{a}} 0.649$ \\
\hline
\end{tabular}

Table 3. The analysis of white blood count subgroups ratio in groups

\begin{tabular}{|l|l|l|l|l|}
\hline \multirow{2}{*}{} & Mean \pm SD & \multicolumn{2}{l|}{ Groups } & \\
\cline { 3 - 5 } & & Non-complicated AA $(\mathbf{n}=164)$ & Complicated AA $(\mathbf{n}=\mathbf{7 1})$ & $\mathbf{p}$ \\
\hline ELR & $0.07 \pm 0.09$ & $0.07 \pm 0.09$ & $0.06 \pm 0.1$ & ${ }^{\mathrm{a}} 0.220$ \\
\hline BNR & $0.01 \pm 0.02$ & $0.01 \pm 0.02$ & $0.01 \pm 0.01$ & ${ }^{\mathrm{a}} 0.191$ \\
\hline BLR & $0.05 \pm 0.16$ & $0.05 \pm 0.15$ & $0.07 \pm 0.18$ & ${ }^{\mathrm{a}} 0.001^{*}$ \\
\hline LLR & $7.8 \pm 7.21$ & $6.52 \pm 5.15$ & $10.77 \pm 10.01$ & ${ }^{\mathrm{a}} 0.001^{*}$ \\
\hline PLR & $0.06 \pm 0.7$ & $0.01 \pm 0.01$ & $0.19 \pm 1.28$ & ${ }^{\mathrm{a}} 0.739$ \\
\hline
\end{tabular}

aMann-Whitney U test, ${ }^{*} p<0.01$, ELR: Eosinophil lymphocyte rate, BNR: Basophil neutrophile rate, BLR: Basophil lymphocyte rate), NLR: Neutrophile lymphocyte rate, LMR: Lymphocyte monocyte rate PLR: Platelet lymphocyte rate, AA: Acute appendicitis, SD: Standard deviation 
Cl: 1.01-1.98, $p=0.046)$, respectively]. The other values such as PLT, PCT, monocyte, eosinophil percentage, BLR and NLR were significant in multivariant analysis $(p>0.05$, Table 4).

Predictive value of significant parameters was analyzed with ROC curve (ROC) analysis. The cut off point for BLR was found to be 0.001 in the groups. The sensitivity, specificity, and positive and negative predictive values for BLR were $67.35 \%, 64.04 \%, 44.6 \%$ and $82 \%$, respectively (Table
5). In addition, the area under ROC and standard error for BLR were found to be $64.9 \%$ and $4.7 \%$, respectively (Figure 1). The cut off point for NLR was found to be 6.56 in the groups. The sensitivity, specificity, and positive and negative predictble values for NLR were $73.47 \%, 66.67 \%$, $48.6 \%$ and $85.4 \%$, respectively (Table 5 ). The area under ROC and standard error for NLR were found to be $72.2 \%$ and $4.1 \%$, respectively (Figure 2 ).

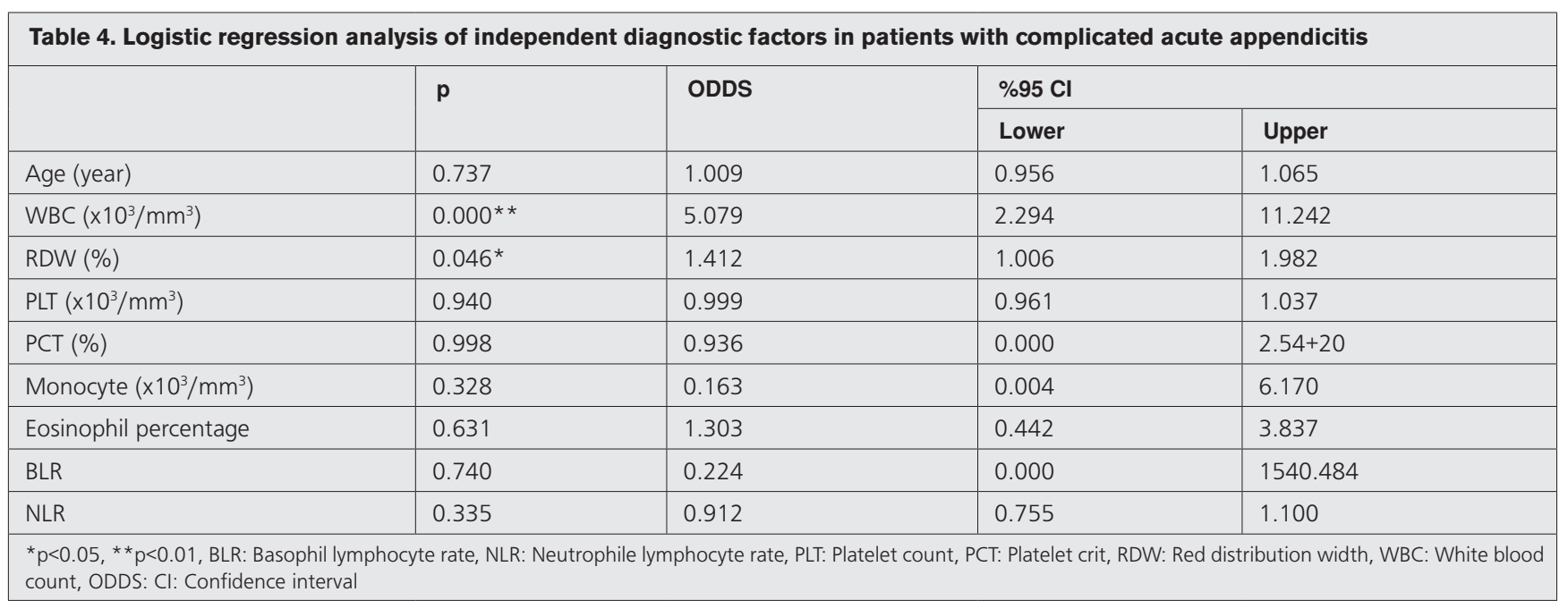

Table 5. Receiver operating characteristic curve for the predictors (basophil lymphocyte rate and neutrophile lymphocyte rate) of patients with complicated acute appendicitis

\begin{tabular}{|l|l|l|l|l|l|l|l|l|}
\hline & \multicolumn{2}{|l|}{ Diagnostic scan } & \multicolumn{2}{l|}{ ROC curve } & p \\
\cline { 2 - 8 } & Cut off & Sensitivity & Specificity & $\begin{array}{l}\text { Positive } \\
\text { predictive value }\end{array}$ & $\begin{array}{l}\text { Negative } \\
\text { predictive value }\end{array}$ & Area & $\begin{array}{l}95 \% \text { confidence } \\
\text { interval }\end{array}$ & $0.003^{*}$ \\
\hline BLR & $\geq 0.001$ & 67.35 & 64.04 & 44.6 & 82.0 & 0.649 & $0.557-0.740$ \\
\hline NLR & $\geq 6.56$ & 73.47 & 66.67 & 48.6 & 85.4 & 0.722 & $0.643-0.802$ & $0.001^{*}$ \\
\hline${ }^{*} p<0.01$, BLR: Basophil lymphocyte rate, NLR: Neutrophile lymphocyte rate, ROC: Receiver operating characteristic & \\
\hline
\end{tabular}

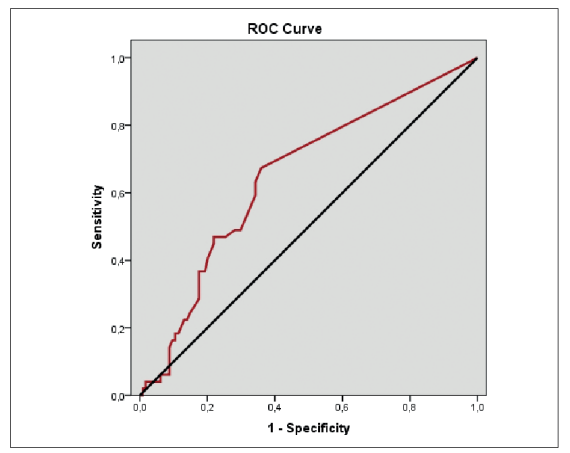

Figure 1. Receiver operating characteristic curve analysis of basophil lymphocyte rate for patients with complicated acute appendicitis

ROC: Receiver operating characteristic

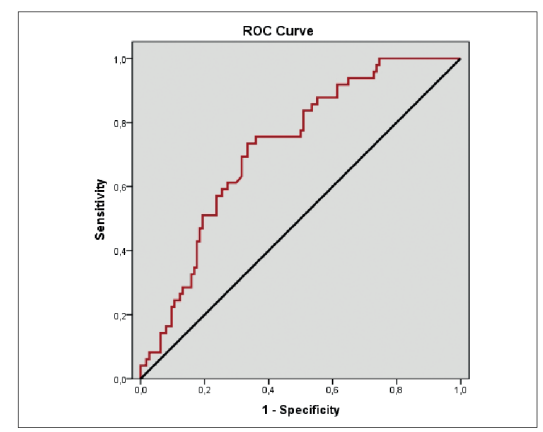

Figure 2. Receiver operating characteristic curve analysis of neutrophile lymphocyte rate for patients with complicated acute appendicitis

ROC: Receiver operating characteristic 


\section{Discussion}

Delayed or inaccurate diagnosis of AA may cause some complications such as perforation or gangrenous AA (23). Radiological imaging can diagnose complicated AA, however, but it may not be available in some hospitals. $C B C$ is relatively cheap and can be available almost in all hospitals. Therefore, $C B C$ has been studied for the diagnosis of $A A$, but the predictive value of $C B C$ in the diagnosis of complicated $A A$ needs to be determined yet. In this study, we found out that some CBC components, such as NLR, BLR, RDW and WBC, have the capacity to differentiate complicated AA from non-complicated AA.

In the current study, the mean age was lower in complicated patients and this is not consistent with a previous study (13). It might be due to the fact that the diagnosis of complicated AA in elderly is easier than in younger patients, since older patients may have more severe symptoms and get more medical attention. There was not any difference in gender between the two groups.

In this study, the results of univariate analysis of $C B C$ revealed that WBC was statistically significantly higher in patients with complicated AA, consistent with some previous studies $(13,14)$. Increased neutrophil count and percentage in complicated AA was consistent with a study reported in the literature (22), while lymphocyte count was not different between complicated and non-complicated AA in this study. The reason for lower lymphocyte percentage was most likely due to higher neutrophil count in complicated $A A$ and needs further study for confirmation. The other components of WBC, such as monocyte and basophil counts, were higher in complicated AA, but the percentages were not diferrent between the two groups and that was also most likely due to higher neutrophil count in complicated AA. There was no difference in eosinophil count between the groups, but the percentage was found to be higher in non-complicated AA due to lower neutrophil and other subgroup of WBC in non-complicated AA. No WBC component was found as an independent diagnostic factor for complicated AA in logistic regression analysis. However, logistic regression analysis showed that elevated WBC was a risk factor for complicated AA [OR 5.079 (95\% Cl: 2.29-11.24)]; that was consistent with the literature (24).

It has been shown that NLR can be used for the diagnosis of AA (14). In this study, consistent with the literature, univariant analysis showed that NLR was statistically significantly higher in complicated $A A(13,14)$. Although NLR was not a risk factor for complicated AA in multivariate analysis, ROC analysis showed that the sensitivity and specificity, and positive and negative predictive values for NLR were $73.47 \%, 66.67 \%, 48.6 \%$ and $85.4 \%$, respectively. We assume that BLR, which was significantly higher in patients with complicated AA, may be a novel parameter for the diagnosis of AA. To our knowledge, no study has showed the value of BLR in AA. In our study, univariant analysis showed that BLR was higher in patients with complicated AA. Although BLR was not an independent diagnostic factor for complicated AA in logistic regression analysis, the sensitivity and specificity, and positive and negative predictive values were $67.35 \%$, $64.04 \%, 44.6 \%$ and $82 \%$, respectively. We found no difference in ELR, BNR, LMR and PLR between the groups.

Our results did not reveal any difference in RBC between the groups. However, (although diagnostic value of RDW in complicated AA has been studied $(17,18)$, Our results did not reveal any difference in $\mathrm{RBC}$ between the groups. Consistent with a previous study that included 215 patients and showed that the level of RDW was statistically significantly higher in AA (25), in this study, RDW was found to be an independent diagnostic factor for complicated AA.

It has been reported that PLT increases in infections (26). In addition, PLT, MPV, PDW, and PCT have been studied to determine whether they can be used for the diagnosis of complicated AA $(15,16)$. There are conflicting reports in the literature; showed that PLT count had no diagnostic value in AA (27), while Aydogan et al. (16) reported that PLT count was significantly increased in complicated AA. In a univariant analysis, our result showed that PLT count was statistically higher in complicated AA. However, it was not found as an independent diagnostic factor in logistic regression analysis. Although some studies have revealed that MPV was significantly decreased in AA $(15,28)$, we did not find any difference between the groups. In the current study, univariant analysis showed that PCT was statistically higher in complicated AA that was consisted with the literature (28). However, logistic regression analysis failed to show PCT as an independent diagnostic factor. Although a previous study reported that PDW increased in complicated $A A$, our study failed to show a significant relationship between PDW and complicated AA (16).

\section{Conclusion}

Elevated NLR, BLR and RDW with increased WBC and neutrophil count may help diagnose complicated AA. Since CBC is available almost in all hospitals, the use of these values will help make timely diagnosis. BLR is a novel indicator that was determined in this study. In conclusion, we assume that NLR, BLR, RDW and WBC values can be used in the diagnosis of complicated AA.

Acknowledgment: We would like to thank Kemal Karakaya, professor of surgery, for his help, and we would also like to thank Emine Bor for her great assistance in statistics. 


\section{Authorship Contributions}

Concept: Y.G. Design: Y.G., S..K., E.Ç. Data Collection or Processing: Y.G., I.T., R.K., S..K., E.Ç. Analysis or Interpretation: Y.G., I.T., R.K., Literature Search: Y.G., S..K., E.Ç. Writing: Y.G.

Conflict of Interest: No conflict of interest was declared by the authors.

Financial Disclosure: The authors declared that this study received no financial support.

\section{References}

1. Andersson RE. Meta-analysis of the clinical and laboratory diagnosis of appendicitis. Br J Surg 2004;91:28-37.

2. Kearney D, Cahill RA, O'Brien E, Kirwan WO, Redmond HP. Influence of delays on perforation risk in adults with acute appendicitis. Dis Colon Rectum 2008;51:1823-7.

3. Doherty GM (Ed.). Current Diagnosis and Treatment, 3rd ed. New York, NY: McGraw Hill, 2010:615-20.

4. Papandria $D$, Goldstein $S D$, Rhee $D$, et al. Risk of perforation increases with delay in recognition and surgery for acute appendicitis. J Surg Res 2013;184:723-9.

5. Prystowsky JB, Pugh CM, Nagle AP. Current problems in surgery. Appendicitis. Curr Probl Surg 2005;42:688-742.

6. Bickell NA, Aufses AH Jr, Rojas M, Bodian C. How time affects the risk of rupture in appendicitis. J Am Coll Surg 2006;202:401-6.

7. Bhangu A, Søreide K, Di Saverio S, Assarsson JH, Drake FT. Acute appendicitis: modern understanding of pathogenesis, diagnosis, and management. Lancet 2015;386:1278-87.

8. Lunca S, Bouras G, Romedea NS. Acute appendicitis in the elderly patient: diagnostic problems, prognostic factors and outcomes. Rom J Gastroenterol 2004;13:299-303.

9. Terasawa T, Blackmore CC, Bent S, Kohlwes RJ. Systematic review: computed tomography and ultrasonography to detect acute appendicitis in adults and adolescents. Ann Intern Med 2004;141:537-46.

10. Verma R, Grechushkin V, Carter D, Barish M, Pryor A, Telem D. Use and accuracy of computed tomography scan in diagnosing perforated appendicitis. Am Surg 2015;81:404-7.

11. Shogilev DJ, Duus N, Odom SR, Shapiro NI. Diagnosing appendicitis: evidence-based review of the diagnostic approach. West J Emerg Med 2014;15:859-71.

12. Tucker A, Sloan K, Gartsin I. White cell counts, CRP and appendicitis - is there a role for pre-operative blood tests? A cohort study. J Health Med Informat 2015;6:185-90.

13. Ishizuka M, Shimizu T, Kubota K. Neutrophil-to-lymphocyte ratio has a close association with gangrenous appendicitis in patients undergoing appendectomy. Int Surg 2012;97:299304.
14. Kahramanca S, Ozgehan G, Seker D, et al. Neutrophil-tolymphocyte ratio as a predictor of acute appendicitis. Ulus Travma Acil Cerrahi Derg 2014;20:19-22.

15. Albayrak Y, Albayrak A, Albayrak F, et al. Mean platelet volume: a new predictor in confirming acute appendicitis diagnosis. Clin Appl Thromb Hemost 2011;17:362-6.

16. Aydogan A, Akkucuk S, Arica S, et al. The analysis of mean platelet volume and platelet distribution width levels in appendicitis. Indian J Surg 2015;77:495-500.

17. Narci $H$, Turk E, Karagulle E, Togan T, Karabulut $K$. The role of red cell distribution width in the diagnosis of acute appendicitis: a retrospective case-controlled study. World J Emerg Surg 2013;8:46-52.

18. Dinc T, Senol K, Yildiz B, Kayilioglu I, Sozen I, Coskun F. Association between red cell distribution width and mean platelet volumewith appendicitis: a myth or a fact? Bratisl Lek Listy 2015;116:499-501.

19. Khan S. Elevated serum bilirubin in acute appendicitis:a new diagnostic tool. Kathmandu Univ Med J KUMJ 2008;6:161-5.

20. Kaser SA, Fankhauser G, Willi N. C-reactive protein is superior to bilirubin for anticipation of perforation in acute appendicitis. Scand J Gastroenterol 2010;45:885-92.

21. Sand M, Bechara FG, Holland-Letz T, Sand D, Mehnert G, Mann B. Diagnostic value of hyperbilirubinemia as a predictive factor for appendiceal perforation in acute appendicitis. Am J Surg 2009;198:193-8.

22. Sevinç $M M$, Kınacı $E$, Çakar $E$, et al. Diagnostic value of basic laboratory parameters for simple and perforated acute appendicitis: an analysis of 3392 cases. Ulus Travma Acil Cerrahi Derg 2016;22:155-62.

23. Jones K, Penn AA, Dunn EL. Are negative appendectomies still acceptable? Am J Surg 2004;188:748-54.

24. Bilici S, Sekmenli T, Goksu M, Melek M, Avci V. Mean platelet volume in diagnosis of acute appendicitis in children. Afr Health Sci 2011;11:427-32.

25. Acar E, Özcan Ö, Deliktaş $H$, et al. Laboratory markers has many valuable parameters in the discrimination between acute appendicitis and renal colic. Ulus Travma Acil Cerrahi Derg 2016;22:17-22.

26. Thomas MR, Storey RF. The role of platelets in inflammation. Thromb Haemost 2015;114:449-58.

27. Tanrikulu CS, Tanrikulu Y, Sabuncuoglu MZ, Karamercan MA, Akkapulu N, Coskun F. Mean platelet volume and red cell distribution width as a diagnostic marker in acute appendicitis. Iran Red Crescent Med J 2014;16:e10211.

28. Gunes ME, Deniz MM, Yılmaz S. Diagnostic value of platelet indices in acute appendicitis and comparison with histopathology. Ann Ital Chir 2017;88:222-8. 